\title{
Dextran Sodium Sulphate (DSS)-Induced Colitis Alters the Expression of Neurotrophins in Smooth Muscle Cells of Rat Colon
}

\author{
M. AL-QUDAH ${ }^{1}$, D. A. SHAMMALA ${ }^{1}$, A. AL-DWAIRI ${ }^{1}$, O. AL-SHBOUL ${ }^{1}$, A. G. MUSTAFA ${ }^{1}$ \\ ${ }^{1}$ Department of Physiology, Jordan University of Science and Technology, Irbid, Jordan
}

Received August 13, 2016

Accepted May 2, 2017

On-line September 22, 2017

\section{Summary}

Neurotrophins are present in the gastrointestinal tract where they participate in the survival and growth of enteric neurons, augmentation of enteric circuits, elevation of colonic myoelectrical activity and also in different aspects of colitis. Previous studies largely focused on the role of neural and mucosal neurotrophins in gut inflammation. The expression of neurotrophins in colonic smooth muscle cells (SMCs) and the interactions of this potential source with colitis has not been studied in the gut. The expression of NGF, BDNF, NT-3 and NT-4 in SMCs from longitudinal and circular muscle layers of rat colon from normal and dextran sodium sulphate (DSS)-induced colitis rats was measured by ELISA. NGF, BDNF, NT-3 and NT-4 are differentially expressed in both longitudinal and circular SMCS, where the expressions of BDNF and NT-4 proteins were greater in SMCs from the longitudinal muscle layer than from the circular muscle layer, while NGF protein expression was greater in circular SMCs and NT-3 expression was equal in cells from both muscle layers. Induction of colitis with DSS significantly alters neurotrophins expression pattern in colonic SMCs. NGF levels upregulated in circular SMCs. BDNF level was increased in DSS-induced colitis in longitudinal SMCs. NGF, NT-3 and NT-4 levels were downregulated in longitudinal SMCs of DSS-induced colitis rats' colon. Disturbances of neurotrophins expression in SMCs resulted from colitis might account for the structural and functional changes in inflammatory bowel disease (IBD) such as loss of innervation and characteristic hypercontractility of longitudinal muscle in IBD.

\section{Key words}

Neurotrophins • Gastrointestinal Tract • Gut Smooth Muscle • Inflammation • DSS • Colitis

\section{Corresponding author}

M. Al-Qudah, Department of Physiology, Jordan University of Science and Technology, Irbid, Jordan. Fax: +962 (0) 27095123. E-mail: maalqudah7@just.edu.jo

\section{Introduction}

Neurotrophins are closely related dimeric proteins that are well characterized in the nervous system. They are involved in many physiological and pathological processes in neuronal tissues, including neuronal survival, regulation of differentiation, migration and activity-dependent synaptic plasticity. In mammals, four different neurotrophins have been identified; nerve growth factor (NGF), brain derived neurotrophic factor (BDNF), neurotrophin-3 (NT-3) and neurotrophin-4/5 (NT-4/5). These factors share more than seventy percent structural homology with NGF (Seidah et al. 1996, Reichardt 2006, Skaper 2008). Neurotrophins activate two distinct classes of plasma membrane receptors with different affinities. The first class is the $\mathrm{p} 75$ receptor which belongs to the tumor necrosis superfamily and is activated by all neurotrophins with low affinity. Tropomyosin-related kinases (Trk) receptors constitute the second class of neurotrophins receptors and include TrkA, TrkB, and TrkC (Chao and Hempstead 1995). Trk receptors are activated specifically with high affinity by one neurotrophin. NGF interacts with TrkA, BDNF and NT-4 interact with TrkB, and NT-3 interacts with TrkC. NT-3 binds to TrkA and TrkB as well, but with less affinity (Seidah et al. 1996, Reichardt 2006, Skaper 2008). 
In addition to their established role in nervous tissues, neurotrophins and their receptors gain relatively recent substantial attention in non-neuronal tissues. They play essential roles in the physiological and pathophysiological processes in several systems (Sariola 2001, Prakash and Martin 2014). One of these non-neuronal systems where neurotrophins are the topic of intense investigation is the gastrointestinal tract (GIT). Several cell types have been identified as a source of neurotrophins in the adult GIT including epithelial and enteroendocrine cells of the mucosa (Lucini et al. 2002, Johansson et al. 2007), enteric neurons and glial cells (Boesmans et al. 2008, Al-Qudah et al. 2015) and recently, BDNF has been identified in intestinal smooth muscle (Al-Qudah et al. 2015). Moreover, several physiological and pathological implications for neurotrophins have been described in the mature gut. For example, BDNF is important in augmenting the peristaltic reflex by enhancing the release of sensory neuropeptides such as serotonin (5-HT) and calcitonin gene relate peptide (CGRP) (Grider and Piland 2007, Chen et al. 2012), enhancing $\mathrm{Ca}^{2+}$ responses to neurotransmitters in enteric neurons and thereby enhancing synaptic transmission (Boesmans et al. 2008), elevating colonic myoelectrical activity (Chai et al. 2003) and recently, we showed that exogenous BDNF enhances cholinergic contraction in smooth muscle strips (Al-Qudah et al. 2014). Another finding showed that BDNF contributes to hypermobility of rat colon during stress (Quan et al. 2015). In clinical trials, BDNF increases gut motility, hastens colonic transit, and increases stool frequency without affecting stool consistency (Bradley and Miller 1999, Coulie et al. 2000, Chen et al. 2014). Furthermore, NGF, BDNF, and NT-3 stimulate the colonic myoelectrical activity of rats (Chai et al. 2003).

In addition to the role of neurotrophins in the normal gut, they are involved in many aspects of gut inflammation (Qiao et al. 2008, Sharon et al. 2012). Neurotrophins expression is altered differentially during colitis and has been linked to changes in gut motility (Geboes and Collins 1998, Reinshagen et al. 2002, Johansson et al. 2007) Additionally, up regulation of neurotrophins in spinal cord and dorsal root ganglion in response to inflammation plays a role in visceral hypersensitivity and the pathogenesis of inflammatory bowel disease and irritable bowel syndrome (Sharon et al. 2012). Dextran sulfate sodium (DSS)-induced colitis is a well-established model to study inflammatory bowel diseases (IBD) such as colitis (Alkahtani et al. 2013, Liu et al. 2014, Reichmann et al. 2015). Changes in neurotrophins' levels have been reported in IBD patients and in colitis models as well. In these studies, neurotrophins-inflammation interactions were reported in mucosal and neuronal cells (Johansson et al. 2007, Qiao and Grider 2010, Gougeon et al. 2013). However, smooth muscle as a source of neurotrophins has not been determined yet.

Little is known about neurotrophins in colon smooth muscle cells and the role of this potential source in gut inflammation; however, in other tissues, neurotrophins produced from smooth muscle play important role at different stages of inflammation (Braun et al. 1999, Prakash et al. 2006, Prakash and Martin 2014). Moreover, neurotrophins modulate several characteristics of smooth muscle physiology such as contractility, proliferative ability and secretion of several cytokines and peptides (Nockher and Renz 2003, Meuchel et al. 2011). Many of these characteristics are altered during gut inflammation. The relationship between neurotrophins and inflammation is particularly interesting especially when neurotrophins role is viewed at different stages of inflammation because they have a dual effect in the process of induction and repair of the disease (Reinshagen et al. 2000, von Boyen et al. 2006, Sharon et al. 2012, Steinkamp et al. 2012). In this study, we show that colonic longitudinal smooth muscle cells (LSMCs) and circular smooth muscle cells (CSMCs) differentially express neurotrophins and experimentally induced colitis by dextran sodium sulphate (DSS) changes their expression pattern.

\section{Material and Methods}

\section{Colitis induction and tissue preparation}

All studies were performed in accordance with the Institutional Animal Care and Use Committee at Jordan University of Science and Technology. Normal adult Sprague-Dawley male rats weighing 150-200 g were nurtured in our university animal house at standard laboratory conditions. Rats were divided into two groups of six rats each. The dextran sodium sulphate (DSS) group received $5 \%$ w/v DSS (MW=40,000 SigmaAldrich Co. LLC, St. Louis, USA) in their drinking water for five days until loose stools, diarrhea, and macroscopically visible blood appeared. Matched control rats received bottled drinking water only. DSS-induced colitis is a well characterized model for colitis that 
exhibited the macroscopic and histological features of colitis (Gaudio et al. 1999, Mizuta et al. 2000, Qiao and Grider 2009). Animal weight, stool consistency, the presence of blood in feces and rectal bleeding were reported on a daily basis to establish the mean disease activity index (DAI) to assess the disease progression (Table 1). The criteria used to calculate the DAI based on parameters such as weight loss $(0$ points $=$ no weight loss to 5 points $=$ more than $15 \%$ weight loss), stool consistency $(0=$ normal to $5=$ watery diarrhea $)$ and bleeding $(0=$ no bleeding, 2 points slight bleeding, 5 points gross bleeding), and recorded as a total of the three scores. DAI for DSS-induced colitis was $7 \pm 3$ (Fig. 2A). Moreover, the proinflammatory cytokines were measured in smooth muscle strips of the distal and compared with the DAI scores (Fig. 2B).

Table 1. Disease activity index (DAI).

\begin{tabular}{lccc}
\hline Score & $\begin{array}{c}\text { Weight loss } \\
\mathbf{( \% )}\end{array}$ & $\begin{array}{c}\text { Stool } \\
\text { consistency }\end{array}$ & $\begin{array}{c}\text { Occult/Gross } \\
\text { bleeding }\end{array}$ \\
\hline 0 & None & Normal & None \\
1 & $1-5$ & & Guaiac \\
2 & $5-10$ & Loose & \\
3 & $10-15$ & Watery & Gross bleeding \\
4 & $>15$ & .
\end{tabular}

The disease activity index (DAI) - combined score of weight loss, stool consistency, and bleeding.

Rats were euthanized by $100 \%$ carbon dioxide $\mathrm{CO}_{2}$ inhalation. The colon was dissected out, emptied of contents, and placed on cold smooth muscle buffer of the following composition $(\mathrm{NaCl} 120 \mathrm{mM}, \mathrm{KCl} 4 \mathrm{mM}$, $\mathrm{KH}_{2} \mathrm{PO}_{4} 2.6 \mathrm{mM}, \mathrm{CaCl}_{2} 2.0 \mathrm{mM}, \mathrm{MgCl}_{2} 0.6 \mathrm{mM}$, HEPES (N-2-hydroxyethyl piperazine-N'-2-ethanesulfonic acid) $25 \mathrm{mM}$, glucose $14 \mathrm{mM}$, and essential amino mixture $2.1 \%$ ( $\mathrm{pH} 7.4$ ). $2-3 \mathrm{~cm}$ sections of the colon were removed and mounted onto glass rod; the fat and mesenteric attachments were removed and the longitudinal muscles were separated from the circular layer by radial abrasion with Kim wipes. The muscle layers were cleared from mucosal/submucosal layers by microdissection and was kept on ice in smooth muscle buffer $\left[\mathrm{NaCl} 120 \mathrm{mM}, \mathrm{KCl} 4 \mathrm{mM}, \mathrm{KH}_{2} \mathrm{PO}_{4} 2.6 \mathrm{mM}\right.$, $\mathrm{CaCl}_{2} 2.0 \mathrm{mM}, \mathrm{MgCl}_{2} 0.6 \mathrm{mM}$, HEPES $25 \mathrm{mM}$, glucose $14 \mathrm{mM}$, and essential amino mixture $2.1 \%(\mathrm{pH} 7.4)$ ] for smooth muscle isolation.
Preparation of dispersed smooth muscle cells and protein extraction

Smooth muscle cells from longitudinal and circular muscle layers of the colon were isolated by sequential enzymatic digestion of muscle strips, filtration, and centrifugation (Murthy et al. 2003, Hu et al. 2008). First muscle strips were incubated for $15 \mathrm{~min}$ at $31^{\circ} \mathrm{C}$ in $30 \mathrm{ml}$ of smooth muscle buffer containing $0.1 \%$ collagenase $(300 \mathrm{U} / \mathrm{ml})$ and $0.01 \%$ soybean trypsin inhibitor. The tissues were continuously gassed with $100 \%$ oxygen during the whole isolation process. The partly digested tissues were washed with $100 \mathrm{ml}$ of enzyme-free smooth muscle buffer and reincubated for $10 \mathrm{~min}$ to allow spontaneous dispersion of muscle cells. Cells were harvested by filtration through $500 \mu \mathrm{M}$ Nitex and centrifuged at $350 \times \mathrm{g}$ for $10 \mathrm{~min}$.

\section{Identification of smooth muscle cells}

The identity of the smooth muscle cells was confirmed by their typical spindle shape appearance of varying length under a 20x objective of an inverted Nikon TMS-f microscope and the dispersed smooth muscle cells were suspended in Dulbecco's Modified Eagle's Medium (DMEM) containing penicillin $(200 \mathrm{U} / \mathrm{ml})$, streptomycin $(200 \mu \mathrm{g} / \mathrm{ml})$, gentamycin $(100 \mu \mathrm{g} / \mathrm{ml})$, amphotericin B $(2.5 \mu \mathrm{g} / \mathrm{ml}$ ), and $10 \%$ fetal bovine serum (DMEM-10). The muscle cells were plated at a concentration of $5 \times 10^{5} \mathrm{cells} / \mathrm{ml}$ and incubated at $37^{\circ} \mathrm{C}$. DMEM-10 medium was replaced every 3 days for 2-3 weeks until confluence was attained. The cultures contained only smooth muscle cells which was confirmed by Western blotting against the smooth muscle-specific marker calponin (anti-calponin antibody ab46794, Abcam, Cambridge, MA, USA) at a 1:500 dilution (Fig. 1). Antibody specificity was confirmed by omitting the primary antibody in the protocol.

Smooth muscle cells were homogenized with solubilization buffer of the following composition, $50 \mathrm{mM}$ Tris-HCl, $150 \mathrm{mM} \mathrm{NaCl}, 1 \mathrm{mM}$ EDTA, $1 \%$ Triton X-100, $100 \mathrm{mM} \mathrm{NaF}$ and containing protease/ phosphatase inhibitor cocktail $(100 \mu \mathrm{g} / \mathrm{ml}$ PMSF, $10 \mu \mathrm{g} / \mathrm{ml}$ aprotinin, $10 \mu \mathrm{g} / \mathrm{ml}$ leupeptin, $30 \mathrm{mM}$ sodium fluoride and $3 \mathrm{mM}$ sodium vanadate). After sonication for $15 \mathrm{~s}$ and centrifugation at $2,000 \times \mathrm{g}$ for $10 \mathrm{~min}$ at $4{ }^{\circ} \mathrm{C}$, the protein concentrations in the supernatant was determined using a DC protein assay kit from Bio-Rad according to manufacturer's directions. 


\section{Western blotting}

Equal amounts of proteins were separated by SDS/PAGE electrophoresis using $10 \%$ and $15 \%(\mathrm{w} / \mathrm{v})$ acrylamide resolving gel. The separated proteins were electrophoretically transferred onto a nitrocellulose membrane, blocked with $5 \%(\mathrm{w} / \mathrm{v})$ non-fat dried milk/TBS-T (Tris-buffered saline, $\mathrm{pH} 7.6$ plus $0.1 \%$ Tween-20) for $1 \mathrm{~h}$ and incubated for $24 \mathrm{~h}$ at $4{ }^{\circ} \mathrm{C}$ with specific neurotrophins primary antibodies (rabbit anti-BDNF antibody, MBS9413508, rabbit anti-NGF antibody, MBS8507345, rabbit Nt-3 antibody, MBS175171, rabbit anti-NT-4 antibody, MBS2524946 MyBioSource, Inc., CA, USA) diluted in TBS-T $1 \%$ $(w / v)$ non-fat dried milk. After washing, the membrane was incubated with horseradish-peroxidase-conjugated secondary antibody $(1: 2,000)$ at room temperature for $1 \mathrm{~h}$. The immunoreactive was visualized by SuperSignal Femto maximum sensitivity substrate kit (Thermo Fisher Scientific. Waltham, MA, USA).

To ensure equal amount of protein loading, in each blot the same membrane was stripped and re-blotted against a housekeeping protein such as beta actin (AC1978, Sigma, St Louis, MO, USA). Densitometric quantification of protein bands was done using the software GelAnalyzer 2010 (http://www.gelanalyzer.com/). The average bands intensity was normalized to that of the control of the same lane.

\section{Neurotrophins ELISA}

Total protein extracts were subjective to commercially available ELISA kits for BDNF $\mathrm{E}_{\max }$ and NGF $E_{\max }$ (both from Promega Corporation, Madison, WI, USA), NT-3 and NT-4 (from R\&D, Minneapolis, MN, USA) according to the manufacturer instructions. Data were expressed as ng or pg per $\mathrm{ml}$ and compared between control groups (circular and longitudinal) versus DSS-induced colitis groups (circular and longitudinal). The appropriate statistical tests were carried out in GraphPad (GraphPad Software, La Jolla, CA, USA). Probability of $p<0.05$ was considered significant. Values are reported as mean \pm SEM. Each experiment was from at least six animals repeated three times.

\section{Pro inflammatory cytokines ELISA}

Total protein extracts from control and DSS-induced colitis smooth muscle strips of rat colon were subjected to ELISA assays specific for TNF- $\alpha$ and IL-1 $\beta$ (Abcam, Cambridge, MA, USA) according to manufacturer instructions. The limit for detection of the
TNF- $\alpha$ and IL- $1 \beta$ ELISA were $82.3 \mathrm{pg} / \mathrm{ml}-20,000 \mathrm{pg} / \mathrm{ml}$ and $31.3 \mathrm{pg} / \mathrm{ml}-2,000 \mathrm{pg} / \mathrm{ml}$, respectively. Data were expressed as pg per total protein extract and compared between control groups versus DSS-induced colitis groups.

\section{Statistical analysis}

Each experiment was performed on SMCs that were harvested from at least six different rats of each group. Statistical analysis of all experiments was performed using Prism software (GraphPad Software, San Diego, CA, USA). The unpaired Student's t-test was used to reveal significant differences between two means. $\mathrm{P}$ value less than 0.05 was required for statistical significance in all the experiments. All data are shown as the mean \pm standard error of the mean.

\section{Results}

In the present study, we examined the changes in expression of the neurotrophins family members by specific ELISA kits and Western blotting in smooth muscle cells of rat colon isolated from control rats and rat with colitis induced with DSS. The identity of smooth muscle cells was confirmed by visual characterization under phase-contrast Nikon light inverted microscope and by culturing the cells until confluence and the subsequent blotting with the specific smooth muscle marker anti-h1calponin antibody. The cells had typical smooth muscle spindle-shape appearance (Fig. 1A) and yielded a strong band at the expected molecular weight of smooth muscle specific antibody $34 \mathrm{kDa}$; anti-h1-calponin antibody (Fig. 1C). TNF- $\alpha$ and IL-1 $\beta$ expression was assessed by specific ELISA kits. Expression of TNF- $\alpha$ and IL- $1 \beta$ was significantly increased (TNF- $\alpha$ in normal: $26.3 \pm 28.46$ vs. DSS-treated: $975.0 \pm 154.8, \mathrm{p}=0.005$; IL- $1 \beta$ in normal: $2,850 \pm 520.4$ vs. DSS-treated: $25,000 \pm 2,646, p=0.0002$ ) in DSS-induced colitis compared to control tissues (Fig. 2). These results strongly indicated the DSS-treatment results in the generation of proinflammatory cytokines and confirmed the inflammation process.

Expression of NGF in smooth muscle cells in rat colon and effect of DSS-induced colitis

ELISA assay showed that NGF is present in smooth muscle cells of normal rat colon, both circular and longitudinal smooth muscle cells contain NGF protein and the circular muscle cells express significantly higher NGF levels than longitudinal muscle 
A

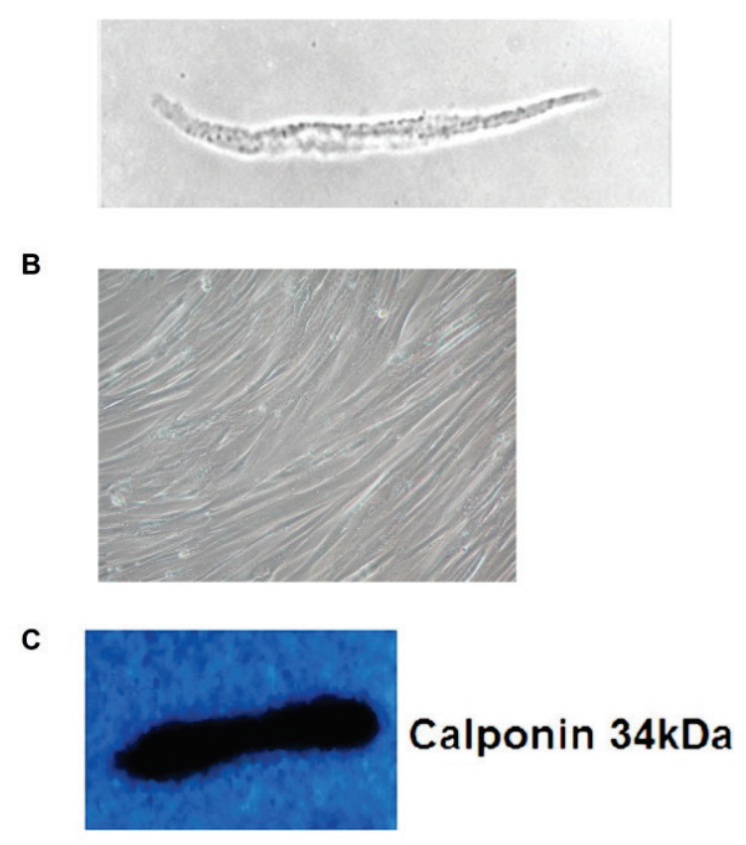

Fig. 1. Isolation and identification of rat colon smooth muscle cells. Smooth muscle cells from the longitudinal and circular colon muscle layer were isolated by sequential enzymatic digestion, filtration and centrifugation. Cells were viewed under a 20x objective of an inverted Nikon phase-contrast microscopy. Cells were of variable length and had a spindle-shaped form $(\mathbf{A})$, and further confirmed by culturing primary isolated cells and blotting with smooth muscle specific marker using anti-h1calponin antibody at 1:1,500 dilution (B, C).

cells (circular: $34.02 \pm 0.4008 \mathrm{ng}$ vs. longitudinal: $24.18 \pm$ $0.1157 \mathrm{ng}$ ) (Fig. 3). These results were further confirmed by Western blotting analysis.

To examine the effect of DSS treatment on NGF levels in both cell types, we compared NGF levels in DSS-induced colitis with those of the control.

DSS-induced colitis resulted in significant downregulation of NGF in the longitudinal smooth muscle cells (control: $24.18 \pm 0.1157 \mathrm{ng}$ vs. DSS-colitis: $20.94 \pm 0.8344 \mathrm{ng}$ ) and had no effect on NGF levels in the circular cells (Fig. 3). Similar results were obtained from Western blotting analysis.

Expression of BDNF in smooth muscle cells in rat colon and effect of DSS-induced colitis

BDNF ELISA and Western blotting assays on total protein extracts from dispersed smooth muscle from rat colon revealed basal expression of BDNF in both longitudinal and circular muscle cells. The expression levels of BDNF was significantly higher in the longitudinal muscle cells than circular muscle cells (Fig. 2, longitudinal SMCs: $177.2 \pm 15.58 \mathrm{ng}$ vs. CSMCs $127.7 \pm 10.38$ ng) (Fig. 4).
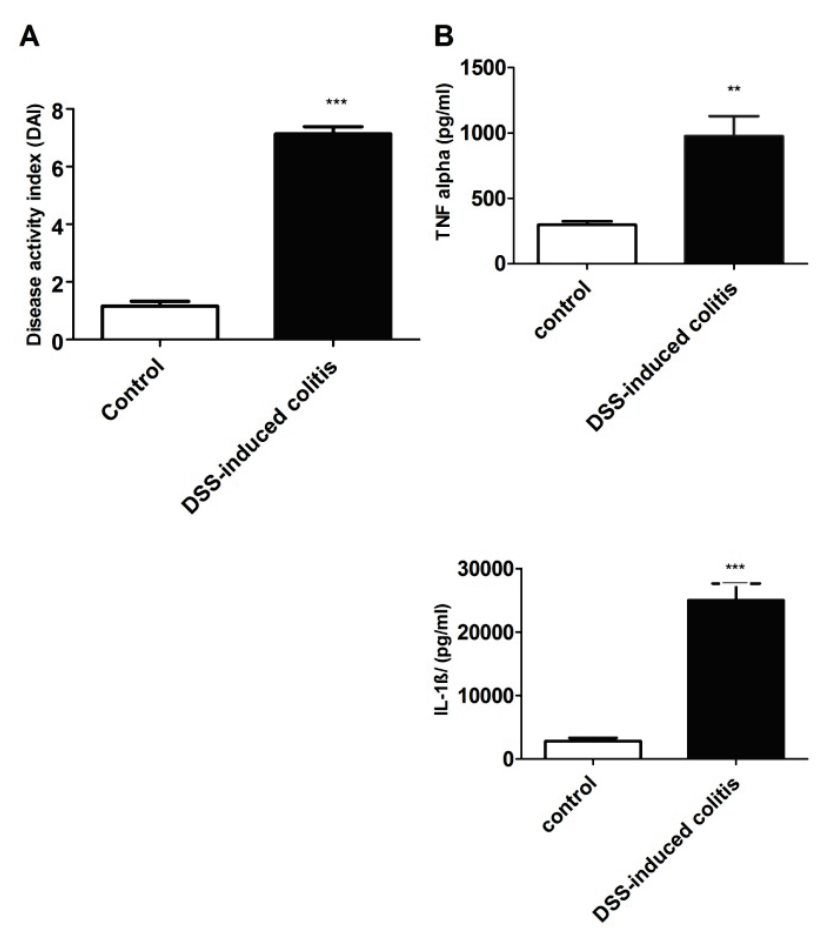

Fig. 2. Induction of colitis by DSS treatment. (A) Male rats were given $5 \%$ DSS in drinking water for 5 days. DAI was calculated at 5 days after DSS treatment as described in Materials and Methods for each group (mean \pm SEM, $n=6$ rats/group). (B) Inflammation was further confirmed by measuring proinflammatory cytokines, TNF-a and IL-1 $\beta$. DSS-induced colitis is associated with elevated TNF-a and IL-1 $\beta$. Values are mean \pm SEM; $* * \mathrm{p}<0.005$; $* * * \mathrm{p}<0.0001$. DSS - dextran sodium sulphate.

When the expression levels of BDNF compared with the DSS-induced colitis group, there was a significant increase of BDNF in the longitudinal SMCs (normal SMC: $177.2 \pm 15.58 \mathrm{ng}$ vs. DSS-colitis: $233.6 \pm 17.73 \mathrm{ng}$ ). The effect of DSS treatment on BDNF level in the circular smooth muscle cells was insignificant (Fig. 4).

Expression of NT-3 in smooth muscle cells of rat colon and the effect of DSS-induced colitis of expression

Our results indicate that NT-3 levels are almost equal in both cell types (Fig. 5) (LSMCs: 78.09 $0.7786 \mathrm{pg}$ vs. CSMCs $80.78 \pm 0.7786 \mathrm{pg}$ ). However, treatment with DSS for 5 days resulted in significant reduction of NT-3 in LSMCs (normal LSMCs: $78.09 \pm 0.7786$ pg vs. DSS LSMCs: $69.99 \pm 0.7786 \mathrm{pg}$ ), and had no effect on NT-3 levels in CSMCs (Fig. 5).

Expression of NT-4 in smooth muscle cells of rat colon and the effect of DSS-induced colitis of expression

Our results showed significant higher basal expression of NT-4 in LSMCs than CSMCs (Fig. 6) (LSMCs: $122.5 \pm 6.967$ pg vs. CSMCs: $102.9 \pm 3.540$ pg). 
A

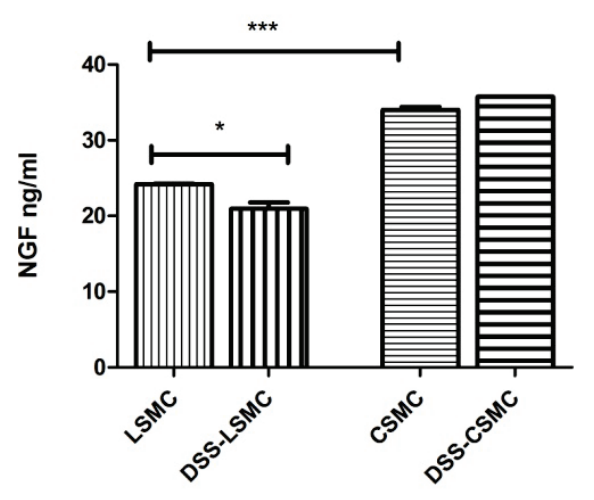

B

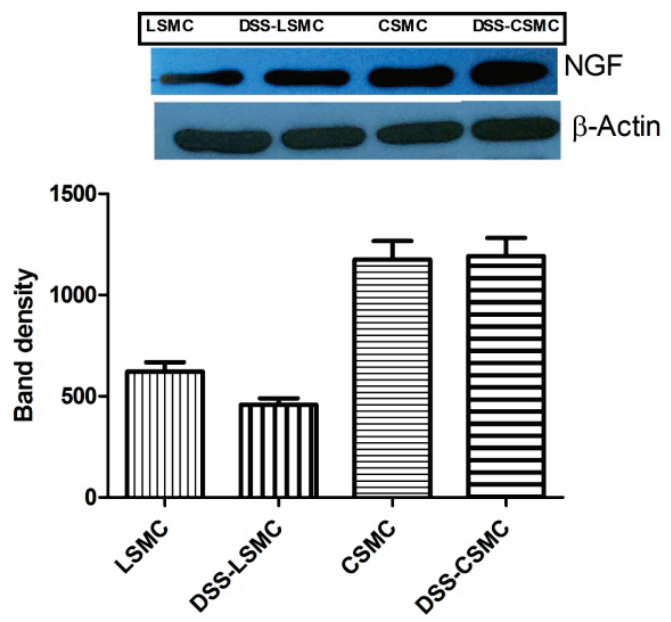

Fig. 3. Expression of NGF in rat colon smooth muscle cells of control and DSS-induced colitis. Rat colon smooth muscle cells contain NGF protein and its expression is greater in smooth muscle cells from the circular muscle layer than from the longitudinal muscle layer. After treatment with $5 \%$ DSS for five days the expression level was decreased in the longitudinal smooth muscle cells. NGF levels (A) was measured by specific ELISA. Western blots (B), optical density of NGF blots was normalized to $\beta$ actin. Inserts illustrate typical blot. Values are mean \pm SEM; $* \mathrm{p}<0.05, * * * \mathrm{p}<0.0001 ;$ LSMC - longitudinal smooth muscle cells, DSS-LSMC - dextran sodium sulphateLSMC, CSMC - circular smooth muscle cells.

Comparing results of the DSS-induced colitis group with those of normal revealed a significant reduction of NT-4 in the LSMCs after colitis induction (normal LSMCs: $122.5 \pm 6.967 \mathrm{pg}$ vs. DSS LSMCs; $93.37 \pm 1.930 \mathrm{pg} \mathrm{N}=4$, ELISA assay), while there was no effect on NT-4 levels in CSMCs (Fig. 6). Western blotting analysis revealed similar results.

\section{Discussion}

In the present study, using specific ELISA kits we have shown that the four neurotrophins family members are constitutively expressed by rat smooth muscle cells. The expression levels of each neurotrophins is different between the LSMCs and CSMCs. The
A
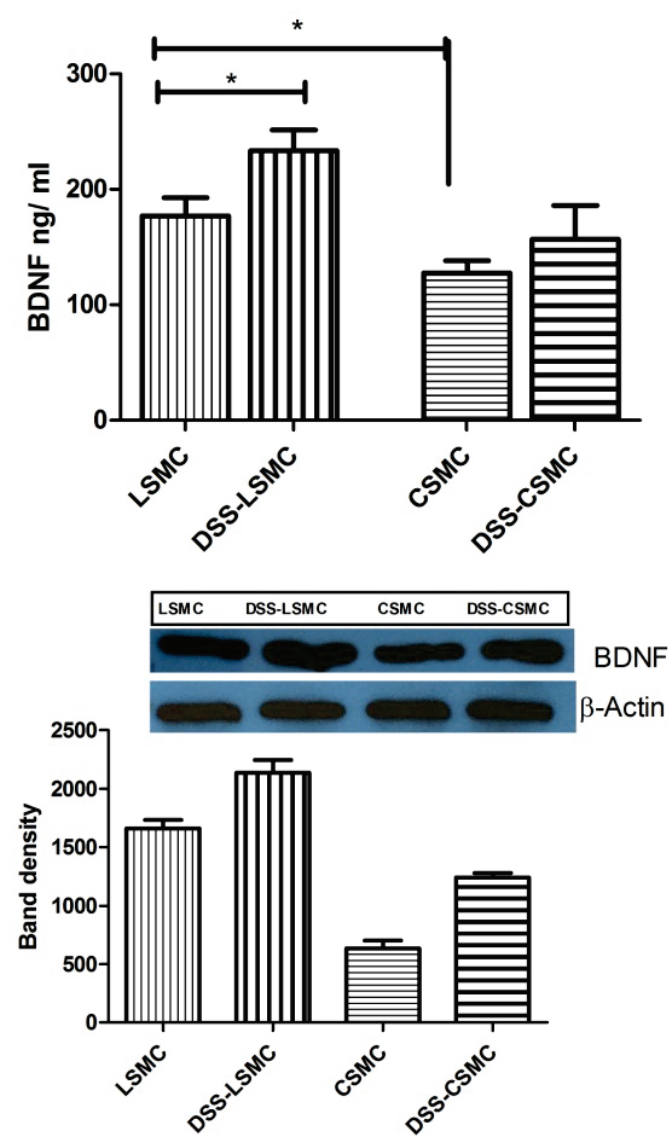

Fig. 4. Expression of BDNF in rat colon smooth muscle cells of control and DSS-induced colitis. BDNF is present in the smooth muscle cells of rat colon and is greater in smooth muscle cells from the longitudinal muscle layer than from the circular muscle layer. Induction of colitis with $5 \%$ DSS for five days led to significant elevation of BDNF content in the longitudinal smooth muscle cells. BDNF levels (A) was measured by specific ELISA. Western blots (B), optical density of BDNF blots was normalized to $\beta$ actin. Inserts illustrate typical blot. Values are mean \pm SEM; * $p<0.05$, LSMC - longitudinal smooth muscle cells, DSS-LSMC dextran sodium sulphate-LSMC, CSMC - circular smooth muscle cells.

induction of colitis by DSS differentially alters the expression pattern in both muscle layers of rat colon.

Neurotrophins present in the wall of the gut in several cell types including mucosal, enteric neurons and glia, and smooth muscle. But most studies have focused on the neuronally-derived neurotrophins because most information came from studies in the nervous system. In the present study, we have examined the expression of neurotrophins in smooth muscle cells and the involvement of this potential source in DSS-induced colitis model. Using specific ELISA kits, we have demonstrated that both the LSMCs and CSMCs contain all members of neurotrophins at different levels. In support to the findings of this study, the neurotrophins system has been identified in smooth muscle tissues in 
A

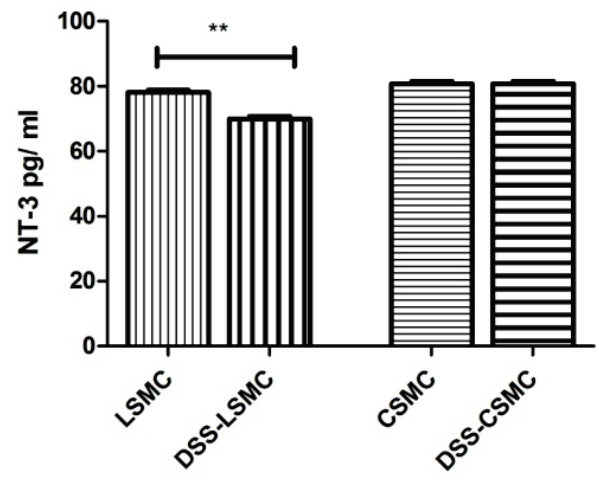

B

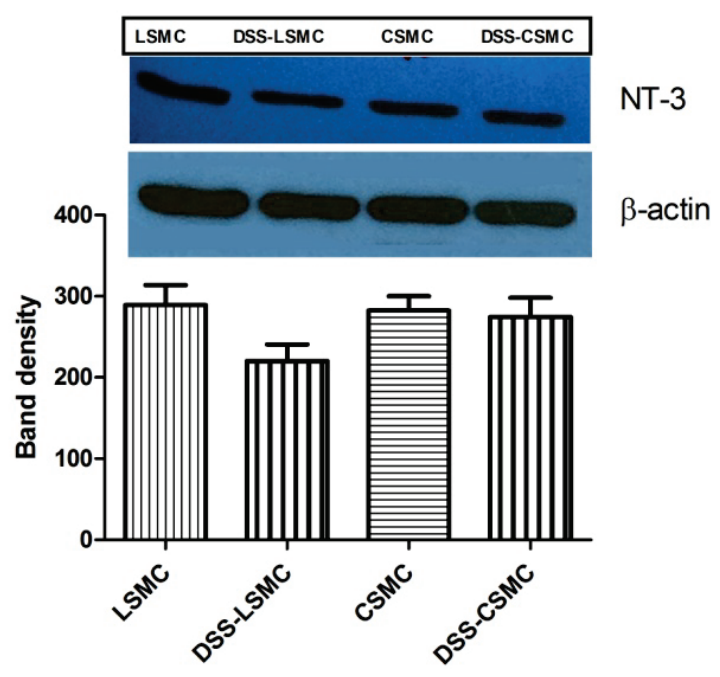

Fig. 5. Expression of NT-3 in rat colon smooth muscle cells of control and DSS-induced colitis. Cells from rat colon express NT-3 in both longitudinal and circular layer. Induction of colitis with $5 \%$ DSS resulted in a significant reduction in the level of NT-3 expression in the longitudinal smooth muscle cells only. NT-3 levels (A) were measured by specific ELISA. Western blots (B), optical density of NT-3 blots was normalized to $\beta$ actin. Inserts illustrate typical blot. Values are mean \pm SEM; $* * p<0.005$, LSMC - longitudinal smooth muscle cells, DSS-LSMC - dextran sodium sulphate-LSMC, CSMC - circular smooth muscle cells.

many organs other than the GIT such as blood vessels (Schaper et al. 2009, Emanueli et al. 2014, Ly et al. 2014), bladder (Girard et al. 2011, Rachaneni et al. 2013), and airways (Renz 2001, Freund and Frossard 2004, Prakash and Martin 2014).

Little is known about neurotrophins and their receptors in smooth muscle cells of mature GIT. However, recently, we have identified that BDNF is present in intestinal smooth muscle and consistent with the present findings; BDNF mRNA and protein were much more prevalent in the longitudinal muscle layer (Al-Qudah et al. 2015). Moreover, BDNF mRNA is abundant in longitudinal smooth muscle isolated from mice intestine (Brun et al. 2015). Furthermore, BDNF expression in gut smooth muscle is important for the development of vagal sensory neurons. Intriguingly,
A

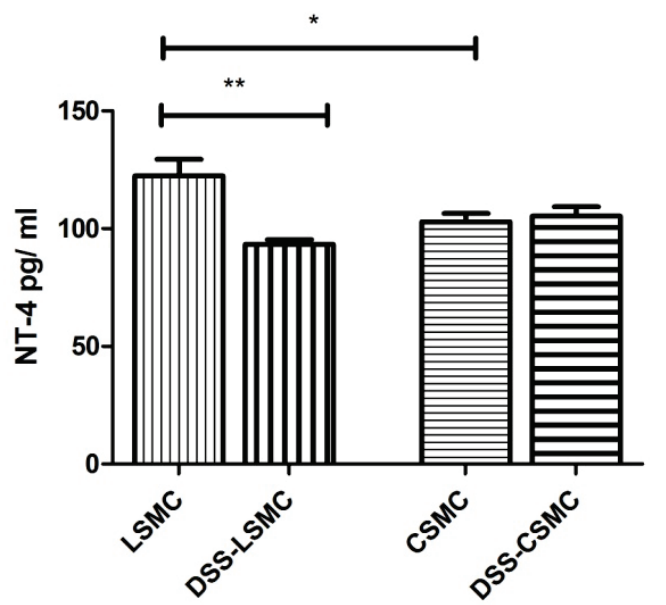

B

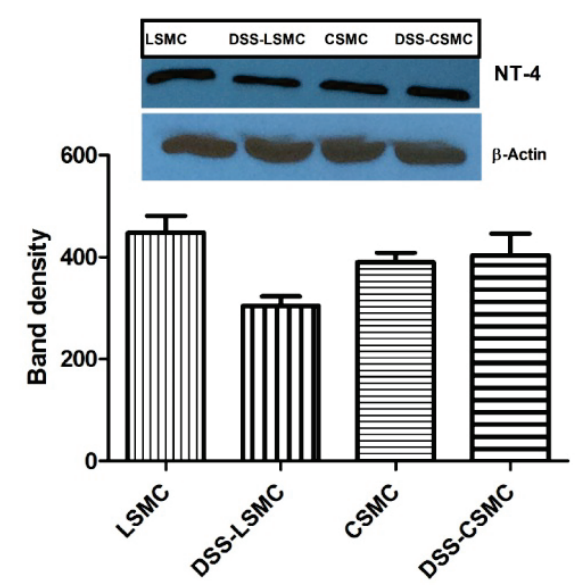

Fig. 6. Expression of NT-4 in rat colon smooth muscle cells of control and DSS-induced colitis. Smooth muscle cells from the longitudinal layer of rat colon contain higher NT-4 than cells from the circular layer. Induction of colitis by $5 \%$ DSS resulted in reduction of NT-4 only in the longitudinal layer. NT-4 levels (A) were measured by specific ELISA. Western blots (B), optical density of NT-4 blots was normalized to $\beta$ actin. Inserts illustrate typical blot. Values are mean \pm SEM; $* \mathrm{p}<0.05, * * \mathrm{p}<0.005$, LSMC - longitudinal smooth muscle cells, DSS-LSMC - dextran sodium sulphate-LSMC, CSMC - circular smooth muscle cells.

BDNF reduction in intestinal smooth muscle of mice resulted in enhanced innervation by vagal sensory neurons which was especially evident in the longitudinal muscle layer. The authors concluded that BDNF normally expressed in longitudinal muscle layer inhibits innervations to this muscle layer (Fox and Biddinger 2012, Biddinger and Fox 2014). These findings might explain the higher expression of BDNF in LSMCs of rat colon. And would also explain the lesser innervation of longitudinal compared to circular muscle by the enteric neurons an observation that is supported by the finding of Grider et al. (1997) that BDNF inhibits neurites outgrowth from cultured myenteric ganglia of guinea pig.

There are very few studies of NGF in gut smooth muscle. However, recent study has identified the expression of NGF in LSMCs from mice ilium (Brun et 
al. 2015). In the same study, NGF from smooth muscle was important for the neuronal integrity. Moreover, overexpression of NGF in smooth muscle of mice colon produces robust collateral sprouting in the descending colon sensory innervations (Elliott et al. 2009, Petrie et al. 2013). The greater expression of NGF in CSMCs reported in the present study may explain the greater innervation of circular muscle than longitudinal muscle by enteric neurons.

The expression of NT-3 and NT-4 in gut smooth muscle has not been addressed in the literature. In our study, we showed that smooth muscle cells from rat colon contain NT-3 and NT-4 in the longitudinal and circular muscle layers. Smooth muscle conditional knockout of NT-3 during development results in severe loss of vagal sensory neuron (Fox et al. 2013). Moreover, NT-4 supports the survival a selective vagal afferent neurons (Fox et al. 2001). The basal expression of NT-3 and NT-4 in mature colon smooth muscle may support the survival of sensory neurons.

There are several reports addressing neurotrophins-gut inflammation relationships. Changes in neurotrophins expression patterns have been described in different inflammatory conditions of the gut such as DSS-induced colitis, parasite infection of the small bowel and in human inflammatory bowel disease (IBD) (Reinshagen et al. 2002, Johansson et al. 2007). Most studies focused on the effect of neurotrophins on neuronal, epithelial, and immune cells in the GIT and attributed changes in function during gut inflammation to these sources of neurotrophins. For example, NGF is overexpressed in mucosal cells during colitis and consisting with our data, BDNF is upregulated in nerve cells in colitis patients (Johansson et al. 2007, Hashmi et al. 2016, Xu et al. 2016). In the present study, we show that smooth muscle cells contribute to the pool of neurotrophins in DSS-induced colitis model. The differential shift of neurotrophins levels in colitis may explain some of the functional abnormalities associated with IBD, especially motility dysfunctions.

Recently, smooth muscle derived-neurotrophins have been implicated in several aspects of inflammation of the airways (Freund-Michel and Frossard 2008, Scuri et al. 2010, Prakash and Martin 2014) and the bladder (Cruz 2014). BDNF levels are increased in smooth muscle tissues of the airways and bladder (Thompson et al. 2014, Frias et al. 2015, Sathish et al. 2015) which are consistent with the upregulation of BDNF in response to DSS-induced colitis which we have demonstrated in the present study in LSMCs. This also may explain, in part the hyper contractility in smooth muscle associated with gut inflammation (Mawe et al. 2004, Khan and Collins 2006, Sarna 2011). Inflammatory cytokines such as TNF- $\alpha$ and IL-1 $\beta$ which others and we identified the increase in their levels during inflammation result in smooth muscle hyperactivity (Al-Shboul et al. 2014). Those cytokines may mediate their hypercontractility effect by inducing the production of BDNF from smooth muscle cells. The upregulation of BDNF in response to inflammatory cytokines is reported in several studies (Johansson et al. 2008, Sharon et al. 2012). In support to this conclusion, we showed previously that exogenous BDNF enhances the cholinergic contractions directly in longitudinal smooth muscle (Al-Qudah et al. 2014). Thus BDNF upregulation in LSMCs in DSS-induced colitis may explain in part the functional and structural changes associated with gut inflammation.

Lastly, this study indicates that NGF, NT-3 and NT-4 levels were reduced in LSMCs after DSS treatment. Supporting findings, immunoneutralization of NT-3 and NGF result in exacerbation of experimental colitis (Reinshagen et al. 2000) suggesting that these factors play a regulatory role in gut inflammation and smooth muscle cells contribute to the process. Further investigations should be conducted to elucidate the exact role of smooth muscle-derived NTs in the normal and inflamed gut.

\section{Conflict of Interest}

There is no conflict of interest.

\section{Acknowledgements}

This work was supported by grant 2015/0038 and 2014/0076 from the Jordan University of Science and Technology. Doa'a Abu Shammala was supported from Qatar Red Crescent.

\section{Abbreviations}

BDNF, brain derived growth factor; CSMCs, circular smooth muscle cells; DAI, disease activity index; DSS, dextran sodium sulphate; ELISA, enzyme-linked immunosorbent assay; GIT, gastrointestinal tract; IBD, inflammatory bowel disease; LSMCs, longitudinal smooth muscle cells; NGF, nerve growth factor; NT-3, neurotrophin-3; NT-4, neurotrophin-4. 


\section{References}

AL-QUDAH M, ANDERSON CD, MAHAVADI S, BRADLEY ZL, AKBARALI HI, MURTHY KS, GRIDER JR: Brain-derived neurotrophic factor enhances cholinergic contraction of longitudinal muscle of rabbit intestine via activation of phospholipase C. Am J Physiol Gastrointest Liver Physiol 306: G328-G337, 2014.

AL-QUDAH M, ALKAHTANI R, AKBARALI HI, MURTHY KS, GRIDER JR: Stimulation of synthesis and release of brain-derived neurotropic factor from intestinal smooth muscle cells by substance $\mathrm{P}$ and pituitary adenylate cyclase-activating peptide. Neurogastroenterol Motil 27: 1162-1174, 2015.

AL-SHBOUL O, NALLI AD, KUMAR DP, ZHOU R, MAHAVADI S, KUEMMERLE JF, GRIDER JR, MURTHY KS: Jun kinase-induced overexpression of leukemia-associated Rho GEF (LARG) mediates sustained hypercontraction of longitudinal smooth muscle in inflammation. Am J Physiol Cell Physiol 306: C1129-C1141, 2014.

ALKAHTANI R, MAHAVADI S, AL-SHBOUL O, ALSHARARI S, GRIDER JR, MURTHY KS: Changes in the expression of smooth muscle contractile proteins in TNBS- and DSS-induced colitis in mice. Inflammation 36: 1304-1315, 2013.

ARAVAMUDAN B, SATHISH V, THOMPSON MA, PABELICK CM, MARTIN RJ, PRAKASH YS: Regulation of brain derived neurotrophic factor secretion during inflammation-induced remodeling in human airway smooth muscle cells. Am J Respir Crit Care Med 191: A5589, 2015.

BIDDINGER JE, FOX EA: Reduced intestinal brain-derived neurotrophic factor increases vagal sensory innervation of the intestine and enhances satiation. $J$ Neurosci 34: 10379-10393, 2014.

BOESMANS W, GOMES P, JANSSENS J, TACK J, BERGHE PV: Brain-derived neurotrophic factor amplifies neurotransmitter responses and promotes synaptic communication in the enteric nervous system. Gut 57: 314-322, 2008.

BRADLEY WG, MILLER RG: Phase III trial of subcutaneous recombinant methionyl human BDNF in patients with ALS. Neurology 52: 1427-1433, 1999.

BRAUN A, LOMMATZSCH M, LEWIN GR, VIRCHOW JC, RENZ H: Neurotrophins: a link between airway inflammation and airway smooth muscle contractility in asthma? Int Arch Allergy Immunol 118: 163-165, 1999.

BRUN P, GOBBO S, CAPUTI V, SPAGNOL L, SCHIRATO G, PASQUALIN M, LEVORATO E, PALÙ G, GIRON MC, CASTAGLIUOLO I: Toll like receptor-2 regulates production of glial-derived neurotrophic factors in murine intestinal smooth muscle cells. Mol Cell Neurosci 68: 24-35, 2015.

CHAI NL, DONG L, LI ZF, DU KX, WANG JH, YAN LK, DONG XL: Effects of neurotrophins on gastrointestinal myoelectric activities of rats. World J Gastroenterol 9: 1874-1877, 2003.

CHAO MV, HEMPSTEAD BL: p75 and Trk: a two-receptor system. Trends Neurosci 18: 321-326, 1995.

CHEN FX, YU YB, YUAN XM, ZUO XL, LI YQ: Brain-derived neurotrophic factor enhances the contraction of intestinal muscle strips induced by SP and CGRP in mice. Regul Pept 178: 86-94, 2012.

CHEN F, YU Y, WANG P, DONG Y, WANG T, ZUO X, LI Y: Brain derived neurotrophic factor accelerates gut motility in slow transit constipation. Acta Physiol 212: 226-238, 2014.

COULIE B, SZARKA LA, CAMILLERI M, BURTON DD, MCKINZIE S, STAMBLER N, CEDARBAUM JM: Recombinant human neurotrophic factors accelerate colonic transit and relieve constipation in humans. Gastroenterology 119: 41-50, 2000.

CRUZ, CD: Neurotrophins in bladder function: what do we know and where do we go from here? Neurourol Urodyn 33: 39-45, 2014.

ELLIOTT J, MACLELLAN A, SAINI JK, CHAN J, SCOTT S, KAWAJA MD: Transgenic mice expressing nerve growth factor in smooth muscle cells. Neuroreport 20: 223-227, 2009.

EMANUELI C, MELONI M, HASAN W, HABECKER BA: The biology of neurotrophins: cardiovascular function. Handb Exp Pharmacol 220: 309-328, 2014.

FOX EA, BIDDINGER JE: Early postnatal overnutrition: potential roles of gastrointestinal vagal afferents and brainderived neurotrophic factor. Physiol Behav 106: 400-412, 2012. 
FOX EA, PHILLIPS RJ, BARONOWSKY EA, BYERLY MS, JONES S, POWLEY TL: Neurotrophin-4 deficient mice have a loss of vagal intraganglionic mechanoreceptors from the small intestine and a disruption of shortterm satiety. J Neurosci 21: 8602-8615, 2001.

FOX EA, BIDDINGER JE, BAQUET ZC, JONES KR, MCADAMS J: Loss of neurotrophin-3 from smooth muscle disrupts vagal gastrointestinal afferent signaling and satiation. Am J Physiol Regul Integr Comp Physiol 305: R1307-R1322, 2013.

FREUND V, FROSSARD N: Expression of nerve growth factor in the airways and its possible role in asthma. Prog Brain Res 146: 335-346, 2004.

FREUND-MICHEL V, FROSSARD N: The nerve growth factor and its receptors in airway inflammatory diseases. Pharmacol Ther 117: 52-76, 2008.

FRIAS B, SANTOS J, MORGADO M, SOUSA MM, GRAY SM, MCCLOSKEY KD, ALLEN S, CRUZ F, CRUZ CD: The role of brain-derived neurotrophic factor (BDNF) in the development of neurogenic detrusor overactivity (NDO). J Neurosci 35: 2146-2160, 2015.

GAUDIO E, TADDEI G, VETUSCHI A, SFERRA R, FRIERI G, RICCIARDI G, CAPRILLI R: Dextran sulfate sodium (DSS) colitis in rats (clinical, structural, and ultrastructural aspects). Dig Dis Sci 44: 1458-1475, 1999.

GEBOES K, COLLINS S: Structural abnormalities of the nervous system in Crohn's disease and ulcerative colitis. Neurogastroenterol Motil 10: 189-202, 1998.

GIRARD BM, MALLEY SE, VIZZARD MA: Neurotrophin/receptor expression in urinary bladder of mice with overexpression of NGF in urothelium. Am J Physiol Renal Physiol 300: F345-F355, 2011.

GOUGEON PY, LOURENSSEN S, HAN TY, NAIR DG, ROPELESKI MJ, BLENNERHASSETT MG: The pro-inflammatory cytokines IL- $1 \beta$ and TNF $\alpha$ are neurotrophic for enteric neurons. $J$ Neurosci 33: 3339-3351, 2013.

GRIDER JR, PILAND BE: The peristaltic reflex induced by short-chain fatty acids is mediated by sequential release of 5-HT and neuronal CGRP but not BDNF. Am J Physiol Gastrointest Liver Physiol 292: G429-G437, 2007.

GRIDER JR, ACEVEDO JR, BUSHMAN T: Inhibition of neurite growth by BDNF, a neurotrophic factor expressed and secreted by myenteric neurons in culture. Gastroenterology 112: A739-A739, 1997.

HASHMI F, LIU M, SHEN S, QIAO LY: Phospholipase C gamma mediates endogenous brain-derived neurotrophic factor-regulated calcitonin gene-related peptide expression in colitis-induced visceral pain. Mol Pain 12, 2016. doi: $10.1177 / 1744806916657088$

HU W, LI F, MAHAVADI S, MURTHY KS: Interleukin-1beta up-regulates RGS4 through the canonical IKK2/IkappaBalpha/NF-kappaB pathway in rabbit colonic smooth muscle. Biochem J 412: 35-43, 2008.

JOHANSSON M, NORRGÅRD Ö, FORSGREN S: Are neurotrophins important in ulcerative colitis? Ann N Y Acad Sci 1107: 290-299, 2007.

JOHANSSON M, JÖNSSON M, NORRGÅRD Ö, FORSGREN S: New aspects concerning ulcerative colitis and colonic carcinoma: analysis of levels of neuropeptides, neurotrophins, and TNFalpha/TNFreceptor in plasma and mucosa in parallel with histological evaluation of the intestine. Inflamm Bowel Dis 14: 1331-1340, 2008.

KHAN WI, COLLINS SM: Gut motor function: immunological control in enteric infection and inflammation. Clin Exp Immunol 143: 389-397, 2006.

LIU GX, YANG YX, YAN J, ZHANG T, ZOU YP, HUANG XL, GAN HT: Glial-derived neurotrophic factor reduces inflammation and improves delayed colonic transit in rat models of dextran sulfate sodium-induced colitis. Int Immunopharmacol 19: 145-152, 2014.

LUCINI C, MARUCCIO L, DE GIROLAMO P, VEGA J, CASTALDO L: Localisation of neurotrophin-containing cells in higher vertebrate intestine. Anat Embryol (Berl) 205: 135-140, 2002.

LY KH, RÉGENT A, MOLINA E, SAADA S, SINDOU P, LE-JEUNNE C, BRÉZIN A, WITKO-SARSAT V, LABROUSSE F, ROBERT PY, BERTIN P: Neurotrophins are expressed in giant cell arteritis lesions and may contribute to vascular remodeling. Arthritis Res Ther 16: 487, 2014.

MAWE GM, COLLINS SM, SHEA-DONOHUE T: Changes in enteric neural circuitry and smooth muscle in the inflamed and infected gut. J Neurogastroenterol Motil 16: 133-136, 2004. 
MEUCHEL LW, STEWART A, SMELTER DF, ABCEJO AJ, THOMPSON MA, ZAIDI SI, MARTIN RJ, PRAKASH YS: Neurokinin-neurotrophin interactions in airway smooth muscle. Am J Physiol Lung Cell Mol Physiol 301: L91-L98, 2011.

MIZUTA Y, ISOMOTO H, TAKAHASHI T: Impaired nitrergic innervation in rat colitis induced by dextran sulfate sodium. Gastroenterology 118: 714-723, 2000.

MURTHY KS, HUIPING ZH, GRIDER JR, BRAUTIGAN DL, MASUMI ET, MAKHLOUF GM: Differential signalling by muscarinic receptors in smooth muscle: $\mathrm{m} 2$-mediated inactivation of myosin light chain kinase via Gi3, Cdc42/Rac1 and p21-activated kinase 1 pathway, and m3-mediated MLC20 (20 kDa regulatory light chain of myosin II) phosphorylation via Rho-associated kinase/myosin phosphatase targeting subunit 1 and protein kinase C/CPI-17 pathway. Biochem J 374: 145-155, 2003.

NOCKHER WA, RENZ H: Neurotrophins in inflammatory lung diseases: modulators of cell differentiation and neuroimmune interactions. Cytokine Growth Factor Rev 14: 559-578, 2003.

PETRIE CN, SMITHSON LJ, CROTTY AM, MICHALSKI B, FAHNESTOCK M, KAWAJA MD: Overexpression of nerve growth factor by murine smooth muscle cells: role of the p75 neurotrophin receptor on sympathetic and sensory sprouting. J Comp Neurol 521: 2621-2643, 2013.

PRAKASH YS, IYANOYE A, AY B, MANTILLA CB, PABELICK CM: Neurotrophin effects on intracellular Ca2+ and force in airway smooth muscle. Am J Physiol Lung Cell Mol Physiol 291: L447-L456, 2006.

PRAKASH YS, MARTIN RJ: Brain-derived neurotrophic factor in the airways. Pharmacol Ther 143: 74-86, 2014.

QIAO LY, GRIDER JR: Colitis induces calcitonin gene-related peptide expression and Akt activation in rat primary afferent pathways. Exp Neurol 219: 93-103, 2009.

QIAO LY, GRIDER JR: Colitis elicits differential changes in the expression levels of receptor tyrosine kinase TrkA and TrkB in colonic afferent neurons: a possible involvement of axonal transport. Pain 151: 117-127, 2010.

QIAO LY, GULICK MA, BOWERS J, KUEMMERLE JF, GRIDER JR: Differential changes in brain derived neurotrophic factor and extracellular signal regulated kinase in rat primary afferent pathways with colitis. Neurogastroenterol Motil 20: 928-938, 2008.

QUAN X, LUO H, FAN H, TANG Q, CHEN W, CUI N, YU G, XIA H: Brain-derived neurotrophic factor contributes to colonic hypermotility in a chronic stress rat model. Dig Dis Sci 60: 2316-2326, 2015.

RACHANENI S, ARYA P, LATTHE P: Urinary nerve growth factor: a biomarker of detrusor overactivity? A systematic review. Int Urogynecol J 24: 1603-1609, 2013.

REICHARDT LF: Neurotrophin-regulated signalling pathways. Philos Trans R Soc Lond B Biol Sci 361: 1545-1564, 2006.

REICHMANN F, HASSAN AM, FARZI A, JAIN P, SCHULIGOI R, HOLZER P: Dextran sulfate sodium-induced colitis alters stress-associated behaviour and neuropeptide gene expression in the amygdala-hippocampus network of mice. Sci Rep 5: 9970, 2015.

REINSHAGEN M, ROHM H, STEINKAMP M, LIEB K, GEERLING I, VON HERBAY A, FLÄMIG G, EYSSELEIN VE, ADLER G: Protective role of neurotrophins in experimental inflammation of the rat gut. Gastroenterology 119: 368-376, 2000.

REINSHAGEN M, VON BOYEN G, ADLER G, STEINKAMP M: Role of neurotrophins in inflammation of the gut. Curr Opin Investig Drugs 3: 565-568, 2002.

RENZ H: Neurotrophins in bronchial asthma. Respir Res 2: 265-268, 2001.

SARIOLA H: The neurotrophic factors in non-neuronal tissues. Cell Mol Life Sci 58: 1061-1066, 2001.

SARNA SK: Lessons learnt from post-infectious IBS. Front Physiol 2, 2011.

SATHISH V, THOMPSON MA, ARAVAMUDAN B, PABELICK CM, PRAKASH YS: Airway smooth musclederived bdnf potentiates inflammation effects on airway remodeling. Am J Respir Crit Care Med 189: A5317, 2014.

SCHÄPER C, GLÄSER S, GRONEBERG DA, KUNKEL G, EWERT R, NOGA O: Nerve growth factor synthesis in human vascular smooth muscle cells and its regulation by dexamethasone. Regul Pept 157: 3-7, 2009.

SCURI M, SAMSELL L, PIEDIMONTE G: The role of neurotrophins in inflammation and allergy. Inflamm Allergy Drug Targets 9: 173-180, 2010. 
SEIDAH NG, BENJANNET S, PAREEK S, SAVARIA D, HAMELIN J, GOULET B, LALIBERTÉ J, LAZURE C, CHRÉTIEN M, MURPHY RA: Cellular processing of the nerve growth factor precursor by the mammalian pro-protein convertases. Biochem J 314: 951-960, 1996.

SHARON JY, GRIDER JR, GULICK MA, XIA CM, SHEN S, QIAO LY: Up-regulation of brain-derived neurotrophic factor is regulated by extracellular signal-regulated protein kinase 5 and by nerve growth factor retrograde signaling in colonic afferent neurons in colitis. Exp Neurol 238: 209-217, 2012.

SKAPER SD: The biology of neurotrophins, signalling pathways, and functional peptide mimetics of neurotrophins and their receptors. CNS Neurol Disord Drug Targets 7: 46-62, 2008.

STEINKAMP M, SCHULTE N, SPANIOL U, PFLÜGER C, KIRSCH J, VON BOYEN GB: Brain derived neurotrophic factor inhibits apoptosis in enteric glia during gut inflammation. Med Sci Monit 18: BR117-BR122, 2012.

VON BOYEN GB, STEINKAMP M, GEERLING I, REINSHAGEN M, SCHÄFER KH, ADLER G, KIRSCH J: Proinflammatory cytokines induce neurotrophic factor expression in enteric glia: a key to the regulation of epithelial apoptosis in Crohn's disease. Inflamm Bowel Dis 12: 346-354, 2006.

XU XJ, LIU L, YAO SK: Nerve growth factor and diarrhea-predominant irritable bowel syndrome (IBS-D): a potential therapeutic target? J Zhejiang Univ Sci B 17: 1-9, 2016. 